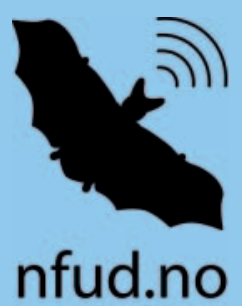

\title{
Fremtidens ultralyd for barnehjerter
}

Solveig Fadnes, Kristian Sørensen og Siri Ann Nyrnes

Institutt for sirkulasjon og bildediagnostikk, NTNU

Teknologiske nyvinninger har gjort det mulig å utvikle ultralydsekvenser basert på planbølger. Disse kan gi ultralydopptak med en billedrate på flere tusen bilder per sekund. Høy billedrate er spesielt viktig ved undersøkelse av hjertet og blodet som hele tiden er i bevegelse. Den økte tidsoppløsningen gir oss mulighet til å bruke ekkokardiografi til å undersøke kortvarige hendelser og raske forandringer i hjertesyklus som ikke er mulig å undersøke med standard ekkokardiografi. Ultralydgruppen ved Institutt for sirkulasjon og bildediagnostikk på NTNU har utviklet flere avbildningssekvenser for høy billedrate og kan vise til spennende resultater i samarbeid med St. Olavs Hospital [1, 2]. Ålesund sykehus er nå inkludert i forskningssamarbeidet, og vi ønsker å studere om de nye ultralydmetodene egner seg til vurdering av hjertefunksjon hos barn.

Vi utnytter den høye billedraten til å estimere blodets retning og hastighet. Dette lar oss generere detaljerte blodstrømskart (> Fig.1). Visualisering og måling av blodstrømsvirvler i hjertekamrene og de store blodårene kan gi ny og klinisk verdifull informasjon.

På figuren har vi brukt den nye metoden til å fremstille en unormal virveldannelse i pulmonalarterien hos et ti dager gammelt barn med pulmonalstenose. MR-studier har tidligere vist en klar sammenheng mel-

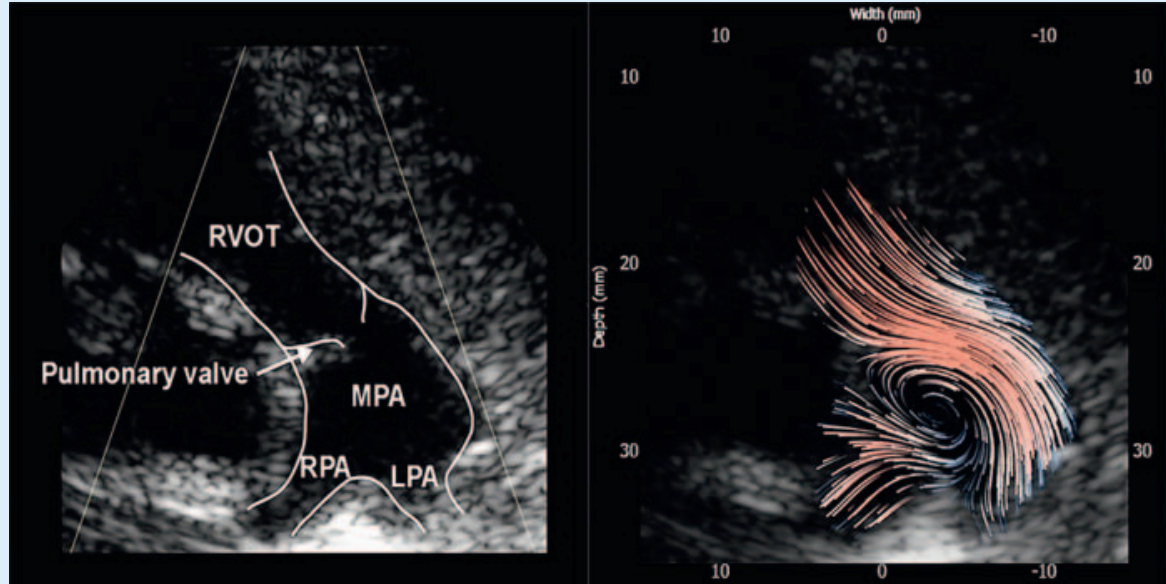

- Fig. 1 Virveldannelse i pulmonalarterien hos et ti dager gammelt barn med pulmonalstenose.

lom virveldannelse og -varighet i pulmonalarterien og pulmonal hypertensjon [3]. Den nye ultralydmetoden kan nå gi oss informasjon som tidligere kun har vært tilgjengelig med MR-undersøkelser.

I tillegg til nøyaktige hastighetsestimat og bedre visualisering av blodstrømmen kan planbølge-ultralyd gjøre det mulig å kvantifisere energitap og trykkgradienter i hjertekamrene. Vi vil sammenligne trykkgradienter i hjertekamrene målt med ekkokardiografi med høy billedrate og farge-Mmode. Vi planlegger laboratorieforsøk og en gjennomførbarhetsstudie før vi starter undersøkelse av en kohort barn 1-18 år og en longitudinell studie av en kohort nyfødte i deres første leveår.

Vi ønsker også å bruke ekkokardiografi med høy billedrate for å fremstille og måle hastigheten av mekaniske bølger som brer seg i hjerteveggen etter klaffelukking. Has- tigheten disse bølgene brer seg med kan være et direkte mål på stivhet i hjertemuskelen, som f.eks. øker ved arrdannelse. Teknikken gir derfor i informasjon om både vevskarakter og hjertefunksjon.

\section{References}

[1] Fadnes S, Wigen MS, Nyrnes SA et al. In Vivo Intracardiac Vector Flow Imaging Using Phased Array Transducers for Pediatric Cardiology. IEEE Trans Ultrason Ferroelectr Freq Control 2017; 64 (9): 1318 -1326. doi:10.1109/TUFFC.2017. 2689799

[2] Wigen MS, Fadnes S, Rodriguez-Molares A et al. 4D Intracardiac Ultrasound Vector Flow Imaging -Feasibility and Comparison to PhaseContrast MRI. IEEE Trans Med Imaging 2018; 1 : doi:10.1109/TMI.2018.2844552

[3] Reiter G, Reiter U, Kovacs G et al. Blood Flow Vortices along the Main Pulmonary Artery Measured with MR Imaging for Diagnosis of Pulmonary Hypertension. Radiology 2015; 275 (1): 71 - 79. doi:10.1148/radiol.14140849 